crowded into the small bookshop, all trying to catch a glimpse of the Gruffalo.

Once the actual book signing commenced, Donaldson's husband took to the street in front of the bookstore and continued to entertain all the visitors still waiting their turn to come inside. Julia Donaldson engaged with all her visitors, having short conversations with each child or parent eagerly awaiting for their book to be signed. It is truly admirable that even after one hour of signing, her husband was still outside, equally cheerful and singing poems inspired by Donaldson's books, along with other popular children's songs upon request.

This meet and greet proved that Julia Donaldson is not only a fantastic writer but also an entertainer at heart. On her website she explains how she started her career busking with her husband, and that until this day they have both enjoyed performing at book festivals. She and her husband prolonged their stay in Zagreb and performed at the Zagreb Book Festival (21-27 May).

It was a pleasure to meet Julia Donaldson but an even greater one to see the enthusiasm inspired by her books and the love of reading she has managed to pass on to yet another generation of children.

Sara Sabljak

\title{
Croatian Children's Books Awards in 2017
}

Hrvatske nagrade za dječju knjigu u 2017. godini

DOI: 10.21066/carcl.libri.2018-07(01).0016

\section{Nagrada „Grigor Vitez" - The “Grigor Vitez” Award}

Ana Đokić. 2016. Bao baobab i mala Kibibi (ilustrirala/images by Dubravka Kolanović) [Bao the Baobab and the Little Kibibi]. Zagreb: Knjiga u centru. (Tekst za djecu / Category: text for children).

Sanja Pilić. 2016. Pošalji mi poruku... [Text me...]. Zagreb: Mozaik knjiga. (Tekst za mladež / Category: text for young adults).

Ana Kadoić. 2016. Što rade odrasli i Petar i tramvaj Kašmira Huseinovića [What Adults Do, text by herself, and Peter and the Tram, text by Kašmir Huseinović]. Zagreb: Kašmir promet. (Za ilustracije za mlađu dob djece / Category: illustration for young children).

Marsela Hajdinjak. 2016. Slavuj Hansa Christiana Andersena [A Nightingale, text by Hans Christian Andersen]. Zagreb: Golden marketing-Tehnička knjiga. (Za ilustracije za stariju dob djece / Category: illustration for older children).

Nagrada „Grigor Vitez“ najstarija je nagrada za dječju knjigu u Hrvatskoj. Dodjeljuje se od 1967. godine u Zagrebu. Osnivač je i pokrovitelj nagrade Savez društava „Naša djeca“"Hrvatske. Dodjeljuje se za najbolji tekst i ilustracije iz jednogodišnje produkcije dječje knjige u Hrvatskoj. Sastoji se od diplome, statue „Ptica“ akademske kiparice Ksenije Kantoci i novčanoga iznosa.

Grigor Vitez (1911-1966) was a Croatian children's poet, translator and editor of children's books. Founded in 1967 in Zagreb by the Union of Societies "Our Children", Croatia, the "Grigor Vitez" Award is the oldest children's book award in Croatia. The best literary text and illustrations selected from Croatia's annual production of 
children's books are awarded a diploma, a bird-shaped statuette (the work of the sculptor Ksenija Kantoci) and prize money.

\section{Nagrada „Mato Lovrak“ - The “Mato Lovrak” Award}

Branka Primorac. 2016. Moj brat živi u kompjutoru [My Brother Lives in a Computer]. Zagreb: Alfa d.d.

Nagrada „Mato Lovrak“ dodjeljuje se u sklopu „Lovrakovih dana kulture“ u Velikome Grđevcu od 1992. godine za najbolji roman za mladež na hrvatskome jeziku objavljen u protekloj godini. Nagrada se sastoji od povelje i novčanoga iznosa.

Mato Lovrak (1899-1974) was a Croatian children's author. The award that bears his name was established in 1992 and is given every year to the best Croatian novel for young adults published in the previous year. The award-giving ceremony is part of the annual "Lovrak Days of Culture" which takes place in Lovrak's place of birth, Veliki Grđevac. The winner is presented with a diploma and prize money.

\section{Nagrada „Anto Gardaš“ - The “Anto Gardaš” Award}

Đurđica Stuhlreiter. 2016. Gašpar i prijatelji [Gašpar and Friends]. Split: Naklada Bošković.

Nagrada „Anto Gardaš“ dodjeljuje se od 2006. godine u Osijeku. Ustanovili su je Društvo hrvatskih književnika (DHK), Zagreb i DHK - Ogranak slavonsko-baranjskosrijemski, Ministarstvo kulture Republike Hrvatske i Grad Osijek. Daje se za najbolji dječji roman ili zbirku pripovijedaka na hrvatskome književnome jeziku. Nagrada se sastoji od povelje i novčanoga iznosa.

To honour the Croatian children's author Anto Gardaš (1938-2004), the Croatian Writers' Association (CWA), Zagreb, CWA - Slavonia, Baranja and Srijem branch, the Ministry of Culture of the Republic of Croatia, and the City of Osijek founded the "Anto Gardaš" Award in Osijek in 2006. The award, which consists of a diploma and prize money, is given for the best children's novel or collection of stories written in standard Croatian.

\section{Nagrada „Ovca u kutiji“ - The “Sheep in a Box” Award}

Dubravka Kolanović. 2017. Čarolija zagrljaja [The Magic of a Hug]. Zagreb: Sipar. (Nagrada stručnoga žirija / Expert Jury).

Davor Šunk. 2017. Fućka mi se [I Couldn’t Care Less]. Zagreb: Hrvatsko društvo književnika za djecu i mladež. (Nagrada dječjega žirija / Children's Jury Award).

„Ovca u kutiji“ književno-likovna je nagrada za najbolju hrvatsku slikovnicu, a dodjeljuje se od 2005. godine u Zagrebu. Organizator nagrade od 2005. do 2007. bila je umjetnička organizacija Autorska kuća. Od 2008. godine nagradu dodjeljuje udruga Knjiga u centru. Nagrada se sastoji od skulpture „Ovca u kutiji“ koju su izradile dizajnerice Korina Hrnčir i Ivana Čukelj. Uz stručni žiri najbolju slikovnicu bira i neovisan dječji žiri. Dodjeljuje se i nagrada publike kada se „Ovca u kutiji“ uručuje u okviru međunarodnoga sajma knjiga Interliber.

Founded in Zagreb in 2005, "Sheep in a Box" is a literary and visual award for best Croatian picturebook. From 2005 to 2007 the award was given by the artistic organisation "The Author's House", and since 2008 by the "Book in the Centre" 
association. The winner, selected by an expert jury, as well as by an independent children's jury, receives the "Sheep in a Box" statuette, made by designers Korina Hrnčir and Ivana Čukelj. When the "Sheep in a Box" is awarded within the Interliber International Book Fair, a special Audience Award is also given.

\section{Nagrada „Zvonko" - The "Zvonko" Award}

Magdalena Mrčela. 2017. Kako je Flegmarin postao kapetan [How Flegmarin Became a Captain]. Zagreb: Hrvatsko društvo književnika za djecu i mlade.

Nagrada „Zvonko“ dodjeljuje se od 2014. godine u Zagrebu za najbolji neobjavljeni rukopis za djecu i mlade. Nagradu dodjeljuje Hrvatsko društvo književnika za djecu i mlade u čast preminulomu književniku Zvonku Todorovskomu, nagrađivanomu autoru za djecu i mlade. Nagrada se sastoji od medalje Zvonka, koju je izradio staklokeramičar Enio Gojević, tiskanja rukopisa te 100 autorskih primjeraka nagrađenoga djela.

Named after the late, prize-winning Croatian children's author and illustrator Zvonko Todorovski (1960-2010), the "Zvonko" Award for best unpublished manuscript for children and young adults was established by the Croatian Writers' Society for Children \& Juveniles in 2014. The winner receives the "Zvonko" medal, made by the glassmaker and ceramicist Enio Gojević, and 100 copies of the published manuscript.

Nagrada „Josip Tabak“: Godišnja nagrada za prijevod djela namijenjenoga djeci i mladima - The "Josip Tabak" Award: An annual award for the translation of a book for children and young adults.

Daniel Bučan, prijevod djela: Fatimah Sharaf al-Din i Intelaq Mohammed Ali (ilust.). 2016. Ibn Batuta: čudesna putovanja (izvorno objavljeno na arapskome 2013.). Zagreb: ArTresor. / Daniel Bučan, for his translation of Fatimah Sharaf al-Din's Amazing Travels by Ibn Battuta (originally published in Arabic in 2013).

Društvo hrvatskih književnih prevodilaca (DHKP) dodjeljuje godišnju nagradu za najbolji književni prijevod u protekloj godini, kao i nagradu za životno djelo „Josip Tabak“. Nagrada se sastoji od povelje i novčanoga iznosa. Godišnja nagrada za najbolji prijevod djela namijenjenoga djeci i mladima dodjeljuje se od 2014. godine.

The Award is named after Josip Tabak (1912-2007), one of the best and most prolific Croatian translators who translated from ten different languages. The award is given by the Croatian Literary Translators Association for the best literary translation in the previous year and for life achievement and it consists of a diploma and prize money. The annual award for the best translation for children and young adults was established in 2014.

Dubravka Težak 